\title{
SEMANTIC BASIS OF ENGLISH AND UKRAINIAN ASTRONOMY TERMS
}

\section{Rohach L.V.}

\section{INTRODUCTION}

In modern linguistics the study of languages in contrastive aspect provides understanding the laws of development of human language, "being the most important means of formation and existence of human knowledge of objective reality" ${ }^{\text {. Contrastive investigation of languages }}$ proved to be extremely captivating as far as "different languages are not different designations of the same subject, but different visions of it" .

Considering rapid development of science and technology in contemporary world, it becomes quite obvious that the problems of contrastive studies of terminological systems of different languages are becoming increasingly relevant both in theoretical and applied aspects. The investigation of structural-semantic peculiarities of terminologies of different language systems appears especially valuable in this respect. The research of the mechanism of transformation of a common language meaning into terminological is a scientific task, the essence of which lies in the analysis of deep processes, that are going on in the semantic structure of a word. From the point of view of relationship between the level of development of terminological systems and scientific and technical progress, linguists quite naturally concentrate their attention on the linguistic background of already existing terminological systems.

In the present paper the main semantic features of English and Ukrainian terms of astronomy as both elements of common language system and words in special function denoting scientific notions are investigated. The scientific relevance of the research is predetermined by

\footnotetext{
${ }^{1}$ Фабіан М.П. Етикетна лексика в українській, англійській та угорській мовах. Ужгород: Інформаційно-видавниче агентство “ІВА”, 1998. - С. 7-8.

${ }^{2}$ Гумбольдт Вильгельм фон. Избранные труды по языкознанию. Пер. с нем. - М.: Прогрес, 1984. - С. 9. 
application of methodology of formalized analysis of lexical units' semantics $^{3}$ aimed at studying semantic peculiarities of astronomy terms in English and Ukrainian. This methodology enabled us to construct matrices of semantic space of the English and Ukrainian terms of astronomy. In the present research matrix description of terminological systems gives the possibility of 1) defining the place of English and Ukrainian terms of astronomy in common language; 2) presenting the structure of their semantics; 3) identifying the connection of astronomical terms of both languages with other terminological units; 4) comparing the semantic space of terminology under study in English and Ukrainian.

In our research we analyze 197 English and Ukrainian terms of astronomy selected from terminological lexicographical sources. The common language meanings of the lexical units are analyzed on the basis of explanatory dictionaries. Applying method of componential analysis, we selected components of meanings from special and common language meanings of lexical units and constructed two matrices designating semantic space of English and Ukrainian terminology of astronomy.

The advantage of the constructed matrices is that besides the reflection of the already realized connections, marked by a certain sign, the empty squares enable the researcher to forecast the location of new lexical units and their ties with the existing terms. It is also of great help in the investigation of the most or the least concentration of terminological elements in the language. In comparative researches the data observed in each language separately are compared and conclusions are made on different levels.

\section{Semantic basis of English terms of astronomy \\ 1.1. Semantic typology in linguistics and terminology}

The current stage of development of linguistics is characterized by the emphasis on typological studies of languages, comparing them with other related and unrelated language systems. Semantic typology deals with expression of meaning in language and languages. Like all branches of

${ }^{3}$ Пещак М.М. Структурування лексичного значення // Формалізовані основи семантичної класификації лексики. - Київ: Наукова думка. - 1982. - С. 56-98. 
linguistic typology, it is concerned with exploring the deep regularities which underlie the incredible diversity in how particular languages work $^{4}$. O.O. Potebnya pointed out that the very idea of comparison of all languages is the same major discovery for linguistics as an idea of mankind history ${ }^{5}$.

Semantic typology lies directly on the lines between psychology, neuroscience, anthropology, the natural sciences, and general linguistics ${ }^{6}$. It primarily studies the linguistic structures themselves and the meanings they express.

The term "typology" has many different uses. In our research typology is understood as "the study of linguistic patterns that are found cross-linguistically, in particular, patterns that can be discovered solely by cross-linguistic comparison". The terms "semantic typology" and "lexical typology" are rarely explicitly defined. Semantic typology is understood as "the systematic cross-linguistic study of how languages express meaning by way of signs" $"$. According to A.J. Lehrer lexical typology is concerned with the "characteristic ways in which language packages semantic material into words" 9 . Lexical typology can be considered a branch of semantic typology concerned with the lexicon.

Nowadays the English and Ukrainian languages not only coexist, but also interact, interpenetrate each other, constantly revealing new combinatorial possibilities, creating qualitatively and quantitatively new systematic groups of terminology ${ }^{10}$. The basic principle of comparative terminology is the principle of consistency. The main methods of systematic comparison of terminology in different languages are as follows:

\footnotetext{
${ }^{4}$ Jakobson Waugh L. On language. -Harvard: Harvard University Press, 1995. P. 5.

5 Потебня А.А. Психология поэтического и прозаического мышления/ Потебня А.А. Слово и миф. - М., 1989. С. 205.

${ }^{6}$ Talmy L. Towards a Cognitive Semantics, 2 vols. Cambridge, MA.: MIT Press. 2000. P. 5.

${ }^{7}$ Croft W. Typology and Universals / Croft W. - Cambridge : Cambridge University Press, 1993. P. 1.

8 Banczerowski J. Some contrastive considerations about semantics in the communication process // Theoretical Issues in Contrastive Linguistics. 1980. Vol. 12. P. 127.

${ }^{9}$ Lehrer A. A theory of vocabulary structure: Retrospectives and prospectives. In Thirty years of Linguistic Evolution. - Amsterdam: John Benjamins. 1992. P. 249.

${ }^{10}$ Фабіан М.П. Етикетна лексика в українській, англійській та угорській мовах. Ужгород: Інформаційно-видавниче агентство “ІВА”, 1998. С. 184 с. 
- establishment of multifaceted, complex relations between the systems of the compared languages (at the lexical, grammatical and semantic levels);

- identification of the characteristics of terminology in these languages in general and the classification of these features;

- comparison of these terminologies detecting preferential use of certain features of a particular language as well as classification of these features;

- contextual and functional analysis, which includes linguistic and quantitative analysis.

Comparative study of multilingual terminology is valuable in that it helps to make a deeper insight into the specific terminology of each language system. Comparative study of terminology is becoming more important nowadays due to the needs of information retrieval, creation of multilingual terminological data banks and scientifically based methods of teaching foreign language experts. The importance of comparative study of the terminology is clear: the creation of dictionaries and translation models based on comparative study contribute to the expansion of relations between scientists from different countries, providing exchange of scientific and technical information.

Traditionally, all languages of the world consist of common language words and words of special domains, which are grouped according to the field and target of usage. In other words, the status of every word depends on the communicative setting in which it is placed and purpose for which it is designed.

The typological study of semantics of astronomical terms assumes the following successive stages: 1) determination of lexical items which describe terms of astronomy as integrated systems that have a certain structural organization, patterns of functioning, the nature of relations between the elements of particular lexico-semantic groups; 2) description of comparable attributes and parameters in accordance with a specific methodology of formalized analysis of lexical units' semantics; 3) semantic componential analysis of astronomy terms; 4) formation of 
lexico-semantic field of terms as a fragment of lexical systems that constitutes a certain semantic space.

Typological study of language semantics can be carried out in several ways, depending on the scale and the place of the language system and on the functioning status of comparable categories. In this respect in modern linguistics there are two most common areas: 1) contrastive study of semantics on the interlingual level and 2) contrastive study of semantic phenomena at the level of one language ${ }^{11}$. The first is realized mainly in typological plane, and preferably at the level of general categories of semantic structure, the comparison of which is aimed at establishing common and different characteristics of basic forms of logical thinking. The comparison process includes units of linguistic semantics of different structural levels of one linguistic system which are based on their hierarchical nature. It is important to conduct the typological study of lexical semantics of lexicological units to penetrate into the semantics of each language in particular, as it can detect semantic nuances invisible during intra-linguistic analysis.

Investigation into the vocabulary of the English and Ukrainian language systems is one of the urgent and widespread problem of modern linguistics. It is closely connected with the construction of the typological model of the interrelation between lexical systems of two different languages. Typological study involves two connected stages: 1) highlighting the most significant features which distinguish semantics in different lexical systems; 2) combining attributes for the selected features.

The typological analysis in the current development of linguistics is made from form to content, and vice versa from content to form. The analysis of the words from meaning to content enables to identify the specific manifestations of the same meanings in different language systems namely to establish the types of interlingual equivalents and to reveal features of semantic connections in the studied languages which are characterized by dynamism. It is generally accepted that semantic change begins in polysemy. Hence a first step in understanding semantic change

${ }^{11}$ Баранник Д.Х. Аспекти зіставного дослідження мовної семантики // Матеріали Респуб. конф. “Проблеми зіставної семантики”. - Київ-Черкаси: ЧДПІ. 1992. - С. 3. 
and the processes that underlie it can be obtained by examining the semantic relations among senses of a polysemous word ${ }^{12}$.

\subsection{Lexico-semantic analysis of English terms of astronomy}

English terms of astronomy were selected from the dictionary "Oxford Dictionary of Astronomy" and their common language meanings were analysed in the explanatory one "Longman Dictionary of Contemporary English". In the present research we treat terms as both elements of common language system and words in special function denoting scientific notions. Thus, studying polysemy in our language material we take into account both common language and terminological meanings.

According to the number of common language meanings in the semantic structure of lexical units we divided our language material into three main groups: terms with the highest degree of polysemy, terms characterized by the average degree of polysemy and monosemantic terms. The group of words with the highest degree of polysemy consists of 13 terms containing more than four meanings in their semantic structure: wave, weight, balance, pressure, mantle, Sun, mass, matter, atmosphere, explosion, opposition.

The term wave is fixed in Oxford Dictionary of Astronomy in the meaning of a disturbance propagating through a continuous medium (Oxford Dictionary of Astronomy). In the explanatory dictionary this term is represented as the one denoting: 1) a line of raised water that moves across the surface of the sea; 2) a sudden increase in a particular type of behaviour, activity, or feeling; 3) a sudden increase in the number of people or things arriving at the same time; 4) the form in which some types of energy such as light and sound travel; 5) a movement in which you raise your arm and move your hand from side to side; 6) a loose curl in your hair; 7) an occasion when many people who are watching an event stand up, move their arms up and down, and sit down again (Longman Dictionary of Contemporary English). As it is obvious from the formulas of explanation, the common language meanings do not define this word as

${ }^{12}$ Koptjevskaja-Tam M., Vanhove M., Koch P. Typological approaches to lexical semantics. Linguistic Typology 11(1): 2007. P. 166. 
a term of astronomy. In our opinion, the lexicographical entry in the explanatory dictionary can be enriched by one more meaning defining this word as an astronomical term: astr. a disturbance propagating through a continuous medium. We consider this term to be formed by means of semantic way of term formation (or terminologization) on the basis of the implicit semantic components being a part of special and common language meanings: continuous movement and increase.

In common language the word pressure is characterized by the meanings: 1) an attempt to persuade someone by using influence, arguments, or threats; 2) a way of working or living that causes you a lot of anxiety, especially because you feel you have too many things to do; 3) the force or weight that is being put on to something pressure of; 4) the force produced by the quantity of gas or liquid in a place or container; 5) a condition of the air in the Earth's atmosphere, which affects the weather (Longman Dictionary of Contemporary English). In the terminology of astronomy the term pressure denotes the broadening of spectral lines from a star due to the high pressure of gas increasing the number of collisions between atoms in a star's atmosphere (Oxford Dictionary of Astronomy). As far as common language and terminological semantics of this lexical unit display dissimilarity, we would recommend to enrich the lexicographical entry in the explanatory dictionary by one more meaning defining this lexical unit as a term of astronomy: astr. the broadening of spectral lines from a star due to the high pressure of gas increasing the number of collisions between atoms in a star's atmosphere. This term in our research can also be treated as a terminologized one on the basis of implicit common semes force and affecting.

Semantic analysis of the first group of English terms of astronomy as terminological and common language lexical units revealed general tendency of their semantics: vast variety of common language meanings fixed in the explanatory dictionary without the meaning in the sphere of astronomy being mentioned at all. In this case, we consider it necessary to add terminological meaning to the explanatory dictionary entry marking it by the lexicographical note astr. The majority of astronomy terms of this 
group were coined from the common language words by means of terminologization on the basis of their likeness.

In the group of words with the average degree of polysemy common language meanings are still represented rather widely. This group consists of 36 terms of astronomy: galaxy, nebula, zenith, accretion, phase, prominence, absorption, wavelength, eclipse, volatile, objective, radiation, constellation, limb, nucleus, light year, radiant, reflector, mare, satellite, spectrum, vibration, transit, aperture etc.

The term galaxy in terminological dictionary is explained as: $a$ collection of a million to a trillion stars, along with gas and dust all held together by gravity (Oxford Dictionary of Astronomy). In the explanatory dictionary this word is represented as denoting several meanings: astr. 1) one of the large groups of stars that make up the universe; 2) a large number of things that are similar; astr. 3) the large group of stars which our sun and its planets belong to; 4) a meeting of rich and famous people (Longman Dictionary of Contemporary English). As we see from the definitions, the first and the third meanings fixed in the explanatory dictionary define this word as a term of astronomy. These meanings are marked by the lexicographical note astr.

The term beam in Oxford Dictionary of Astronomy is defined as a stream of radiation or particles confined to a narrow range of directions. In the explanatory dictionary this term is represented as denoting: 1) astr. $a$ line of light that shines from a bright object; 2) phys. a line of radiation or particles flowing in one direction; 3) long heavy piece of wood or metal used in building houses, bridges etc; 4) a wide happy smile (Longman Dictionary of Contemporary English). The analysis of semantics of the term beam allows us to state that this term acquired meanings simultaneously in astronomy and physics. Thus, in this case we observe interdisciplinary polysemy.

The term mass in Oxford Dictionary of Astronomy denotes: $a$ measure of the amount of matter in a body. In Longman Dictionary it is fixed as: astr. 1) a large amount of a substance which does not have a definite or regular shape; 2) a large crow; 3) the amount of material in something; 4) the main ceremony in some Christian churches, especially 
the Roman Catholic Church, which celebrates the last meal that Jesus Christ ate. It is obvious that both explanatory and terminological dictionaries define this lexical unit as a term of astronomy. Besides, according to the information given by Longman Dictionary lexical unit mass can be also treated as a religious term. These relations we tend to define as homonymic, not observing explicit connections between terminological meanings in astronomy and religion.

The term wavelength in the dictionary of astronomy indicates the distance between successive peaks or troughs of a wave (Oxford Dictionary of Astronomy). In Longman Dictionary this lexical unit is explained as: 1) the size of a radio wave used to broadcast a radio signal; astr. 2) the distance between two points on energy waves such as sound or light (Longman Dictionary of Contemporary English). The semantics of this lexical unit reveals its strong scientific character, being not only a term of astronomy, but the one of physics. In the semantic space of terminology of astronomy these lexical meanings are connected by common semes distance and size.

The English words of our language material constituting the second group are in their majority terms of different sciences. In some cases, we treat this phenomenon as intersystem polysemy, tracing the same components of meaning in their semantic structure; in other cases, they can be viewed as the examples of homonymy. Most common language meanings characterizing this group are closely connected with terminological ones being in some cases primary, but in other secondary.

Monosemy is a term - concept assignment, in which one concept only is assigned to a term. Considering the alleged characteristics of terms (precision, emotional neutrality and stability), every term should be monosemantic, but this only happens with the new terms (not altered by other meanings or connotations) if they were not formed using pre-existing words, specialized or not. The monosemy of terms can be proved by the fact that it is one of the basic requirements to be met by terms. A great number of monosemantic words can be found among terms of astronomy, the very nature of which requires precision.

The third group of our material is composed of the terms the formulas of explanation of which fixed in both types of dictionaries coincide. All 
monosemantic words of our research material are only terms of astronomy. The third group includes 148 monosemantic lexical units. As far as this group is the largest one in our language material, it can be divided into several thematic subgroups.

- Names of astronomical objects: asteroid, bolide, comet.

The term bolide is a fireball accompanied by one or more audible explosions, often associated with meteorite falls (Oxford Dictionary of Astronomy). Longman Dictionary provides the same meaning: a fireball that produces a sonic boom (Longman Dictionary of Contemporary English).

- Names that indicate the trajectory of objects movement: ecliptic, axis, zodiac.

In terminological dictionary the term ecliptic is fixed as the apparent path of the Sun against the star background over the course of a year (Oxford Dictionary of Astronomy). In Longman Dictionary this term is defined similarly: the path along which the sun seems to move.

- Names of natural phenomena: eruption, explosion.

As a term of astronomy lexical unit eruption is explained as a process during which molten rock (magma) and/or volcanic ash flows to the Earth's surface (Oxford Dictionary of Astronomy). In the explanatory dictionary the meaning of the term eruption is similar to that indicated in the special dictionary: eruption the release of gas, ash, molten materials, or hot water into the atmosphere or onto the Earth's surface from a volcano... (Longman Dictionary of Contemporary English).

As we see, the definitions of monosemantic words of our language material, given by the special and explanatory dictionaries are similar and in some cases even identical. We have come to the conclusion that these lexemes have almost no connections with other words in the semantic space of the English terminology of astronomy.

\subsection{Seme analysis of English astronomy terminology}

The structure of the majority of lexical items consists of a large number of signs by which words, on the one hand, belong to different conceptual fields, on the other intercross and complement each other 
within a single lexico-semantic field. The semantic basis of astronomical words allows to single out their major and minor meanings. The definition of the astronomical terms is presented in the form of their interpretation, the semantic enrollment.

The analysis of seme composition of the English terms of astronomy is performed by means of selection of semes from words' dictionary definitions. Seme analysis of lexical unit's semantics should give deep, thesaurus definition, in which more semantic features will be highlighted ${ }^{13}$. The seme composition of the English astronomy terms, as well as the lexical one, is represented in the matrix, what enables us to treat semes as the elements of systemic and structural groups. Quantitative and qualitative characteristics of semes determine the word's semantic importance and its connections with other lexical units ${ }^{14}$.

In our research we conducted the formalized analysis of the semantics of 197 English astronomical terms. The application of componential analysis of semantics of English astronomical terms enabled us to select 111 semes from common language and terminological meanings. In the constructed matrix of the semantic space of the English terms of astronomy the list of semes is located horizontally in descending order.

According to quantitative parameter we distinguish polyfunctional semes; semes of average degree of occurrence and monofunctional semes. The polyfunctional semes in the matrix occupy the first place and unite semantics of the majority of lexical units of our material (from 39 to 11). The semes of average degree of occurrence unite the semes that were singled out from the meanings of average quantity of words (from 10 to 2). Monofunctional semes were selected from the meanings of only one lexical unit.

Most multifunctional semes reflect common language and terminological semantics. In this group the common language semantics is presented by a great number of seme realizations that form different

13 Васильев Л.М. Достоинства и недостатки компонентного анализа в семантических исследованиях // Исследования по семантике. Межвуз. сб. - Уфа: Изд-во Башкирского университета, 1984. С. 5.

${ }^{14}$ Фабіан М.П. Етикетна лексика в українській, англійській та угорській мовах. Ужгород: Інформаційно-видавниче агентство “ІВА”, 1998. С. 115. 
connections. Some examples of multifunctional semes: object, star, light, body, particle, surface, energy, mass, system, space, dust, matter, line, temperature, field etc. For instance, the polyfunctional terminological seme object is represented in terminological semantics of the following terms: nebula, parallax, gravitational lenz, scintillation, radial velocity, weight, radar, red shift, accretion disk, meteorite, azimuth, transit, asteroid etc. The same seme was detected in the common language semantics of such lexical units: pressure, mantle, phase, nadir, orbit, altitude etc. In the semantics of the term asteroid this seme was singled out from the following meaning: any of the many small rocky or metallic objects in the Solar System... (Oxford Dictionary of Astronomy).

The seme star was selected from the meanings of the terms: galaxy, white dwarf, lenticular galaxy, absolute magnitude, photosphere, luminosity, open cluster, supernova, eclipsing binary, protostar, quasar etc. The seme light is an element of the semantic structure of the terms: photon, red shift, albedo, objective, meteor, aurora, black hole, light year, light cone, reflector. The special semantics of the term spectrograph is a device for dispersing light into a spectrum... (Oxford Dictionary of Astronomy).

The semes of the average degree of occurrence are line, gravity, brightness, effect, measure, position, element, velocity, plane, hole, material, disk, wavelength, direction, sphere, explosion, core, pressure, centre, emission, diameter, movement, appearance, shadow, cluster, particle, space, portion, interval etc. For example, the polyfunctional terminological seme line represents special semantics of the following terms: pressure, radial velocity, luminosity, eclipsing binary, terminator, axis, scarp and in the common language semantics of the terms zenith and axis. The seme gravity is an element of the semantic structure of the terms galaxy, substorm, weight, atmosphere. The seme core we single out from the semantics of the term nucleus (the central core of an atom that contains most of its mass) (Oxford Dictionary of Astronomy).

The monofunctional semes of our language material are: displacement, transfer, accumulation, circle, association, practice, interaction, spin, neutral, universe, evolution, eruption, condition, circular, 
declination, flexure, depth, vector etc. The specificity of the research prompted the necessity of division of the monofunctional semes into the common language ones and those of terminological character.

According to qualitative parameter the semes of our language material are divided into: descriptive (manner, form, measure, degree, feature, qualities, condition etc.); relative (function, effect, relation, repetition, conversion, function, movement etc.); objective (element, object, particle, portion, sphere, interval, line etc.)

\section{Semantic basis of Ukrainian terms of astronomy}

\subsection{Lexico-semantic analysis of Ukrainian terms of astronomy}

The role of a dictionary, especially that of an explanatory one, which forms the empirical basis of modern semantics, is well known and generally accepted. Lexicographic practice constantly and consistently directs researchers to study lexical meaning of an individual word not as an isolated one but naturally dependent element of language system as a whole ${ }^{15}$. Explanatory dictionaries represent a concrete word in its numerous connections with other components of a word-combination and reflect lexical composition of language as a system with inherent semantic, lexicalgrammatical, stylistic connections in different correlations and oppositions.

The semantic structure of any system of words in a dictionary is a network of semantic relations observed between the words of a particular system ${ }^{16}$. The study of dictionary explanations of lexical units in our research is important as "broad analytical definitions, that we treat as the samples of more or less adequate division of meanings of one words into the meanings of other lexical units, are extremely valuable for componential analysis" $"$.

In modern lexicography the problem of terminological lexis reflection in the explanatory dictionary is relevant, though not fully investigated. The

15 Пещак М.М. Нариси 3 комп'ютерної лінгвістики: Монографія. Ужгород: Закарпаття, 1999. С. 58.

${ }^{16}$ Сорока Т.В. Особливості полісемантичної структури аксіономенів сучасної англійської мови // Сучасні дослідження з іноземної філології. Збірник наукових праць. Ужгород. Вип. 13. 2015. С. 198.

${ }^{17}$ Фабіан М.П. Етикетна лексика в українській, англійській та угорській мовах. Ужгород: Інформаційно-видавниче агентство “ІВА”, 1998. С. 43. 
complexity of this issue research is that the terminological vocabulary that enters the codified literary language from the scientific and technical sphere forms a very significant part of the vocabulary register of each common language dictionary. The specificity of the semantic characteristic of a term in the explanatory dictionary is expressed in the need to take into account scientific knowledge when characterizing the conceptual component of meaning, rigid fixation of its semantics and the possibility of choosing of the most spread understanding of the term.

The problems connected with the incorporation of terminological vocabulary into the literary language dictionary are as follows: 1) selection of terminological lexis for the dictionary; 2) correlation of extralinguistic content and semantic structure of a term with its linguistic description in the dictionary; 3) functioning of a term in a particular sphere of human activity; 4) dictionary presentation of the semantic structure of a term; 5) term combinability; 6) stylistic characteristic of a term.

Terminology dictionaries compilers are struggling with a whole range of issues that they share with lexicology. Among these issues, difficulties in the identification of terms, polysemy and synonymy, a great quantity of abbreviations, and rapid expansion of the terminological system ${ }^{18}$.

In terms of application of methodology of formalized analysis of semantics lexical units of Ukrainian terminology of astronomy were divided into three groups on the basis of their degree of polysemy: terms with the highest degree of polysemy, terms characterized by average degree of polysemy and monosemantic terms. The group of words with the highest degree of polysemy consists of 13 lexical units containing more than four meanings in their semantic structure: сонце, висота, маса, земля, оболонка, матерія, опір, сфера, тінь, вага, градус, сила, фаза.

The term соние in the Ukrainian special dictionary of astronomy indicates the closest star to us, the central body of the solar system (найближча до нас зоря, центральне тіло Сонячної системи) (Астрономічний енциклопедичний словник) and in the Ukrainian explanatory dictionary the meanings are the following: 1) астр. central orb

${ }^{18}$ Gordienko O. Some issues of English medical terminography in the context of English globalization // Сучасні дослідження з іноземної філології: Збірник наукових праць. Вип. 17. Ужгород: ДВНЗ “УжНУ”, 2019. С. 28. 
of solar system that takes the form of hot giant ball that emits light and heat (центральне небесне світило сонячної системи, щьо має форму гігантської розжареної кулі); 2) reflection of something in something of this heavenly body (відбиття, відображення чим-небудь або у чомусь изього небесного світила); 3) light and heat emitted by this star (світло й тепло, що випромінюються иим світилом); 4) something that illuminates the way, the one who leads the way (in life, fighting, etc) (те, що освітлюе илях, той, хто веде за собою (у житті, боротьбі i m. ін.); 5) астр. central planet of other planetary systems (иентральна планета інших планетних систем) (Великий тлумачний словник сучасної української мови). As it can be seen from the definitions, the first and the fifth meanings fixed in the explanatory dictionary define this word as a term of astronomy. They are marked by the lexicographical note acmp.

The term фаза in terminological dictionary denotes: a different form of the solar system (planets, planetary satellites, asteroids, comets) which the observer sees from the Earth (Астрономічний енциклопедичний словник). The Ukrainian explanatory dictionary gives five formulas of explanation of this lexical unit: 1) period, the stage of development of a phenomenon, process, etc. (період, стадія в розвиткові якого-небудь явища, прочесу тощо); 2) the specific point in changing the shape or condition of something (положення, певний момент у зміні форми або стану чогось); 3) хім. homogeneous part of any heterogeneous physical and chemical systems (однорідна частина якої-небудь неоднорідної фізико-хімічної системи); 4) геол. the smallest period, which corresponds to a certain character species (найменший період, якому відповідає певний характер порід); 5) біол. some stage in individual development of a body (певний етап в індивідуальному розвиткові якогось організму) (Великий тлумачний словник сучасної української мови). The analysis of astronomical term allows us to state that the term фаза developed simultaneously in different fields of science, i.e.in chemistry, geology and biology. We would suggest to enrich the semantics described in the explanatory dictionary by a special meaning in astronomy. The terminological meanings in astronomy and chemistry testify to the fact 
that these meanings developed separately from the rest of special ones. Other scientific meanings are united by such common semes - nepiod, етап, момент.

The analysis of the first group of our language material showed that the terms of this group are characterized by interdisciplinary polysemy. We can state that the similarity of semantic processes in different spheres of human activity underlies this phenomenon. The similar features are observed in these terminological systems with different degrees of intensity and concern various objects.

In the group of words with the average degree of polysemy common language meanings are still represented rather widely (from 4 to 2 meanings). To this group belong 43 terms of astronomy: хвиля, тиск, орбіта, зсув, мантія, супутник, аберація, атмосфера, зірниця, конвекиія, вибух, коливання, освітленість, апогей, баланс, лавина, резонанс, спектр, термінатор, масштаб, виверження, промінь, ореол, скупчення, рефлектор, ескарп, видимість еtс.

The composition of this group of terms of astronomy allows division into several thematic subgroups.

- Names of devices, mechanisms: спектограф, рефлектор.

Cnектограф in the dictionary of astronomy is described as spectral instrument in which registers the maximum possible electromagnetic spectrum deployed in the focal plane of the optical system (Астрономічний енциклопедичний словник). Explanatory dictionary suggests two meanings of this word: 1) the optical device designed for photographing of spectra (оптичний прилад, призначений для фотографування спектрів); 2) apparatus for analyzing the composition oscillation frequency of the mechanical and electromagnetic origin (прилад для аналізу частотного складу коливань механічного та електромагнітного походження) (Великий тлумачний словник сучасної української мови). Both dictionaries suggest terminological meanings of the lexical unit, the explanatory dictionary in this case being more precise.

- Names of the orbit's point: апогей, афелій, перигелій. 
In terminological dictionary the term апогей is explained as the point of the orbit of the moon or an artificial satellite of the Earth, most distant from Earth (точка орбіти Місяця або штучного супутника Землі, найвіддаленіша від цеентра Землі) (Астрономічний енциклопедичний словник). In the Ukrainian explanatory dictionary this meaning is rendered as: астр. 1) the farthest point of the Earth's orbit of the moon or an artificial satellite (найвіддаленіма від центра Землі точка орбіти Місяия або штучного супутника Землі); 2) the highest degree of something; peak, flowering (найвищий ступінь чого-небудь; вершина, розквіт). The analysis shows that terminological and common language meanings are characterized by a common seme - вериина.

- Names that indicate the displacement of objects: паралакс, екліптика.

The term паралакс in the dictionary of astronomy is explained by one meaning: the phenomenon of apparent displacement of the body (object) (явище видимого зміщення тіла (предмета)). In the explanatory dictionary this term is represented as denoting: 1) apparent displacement of the proposed facility as a result of displacement of the observation point; 2) астр. angle measuring apparent bias lights when moving observer from one point in space to another. The first meaning in the explanatory dictionary coincides with the one fixed in the terminological dictionary. So, in our opinion, this term is polysemantic in astronomy, denoting two scientific concepts, which is demonstrated by the explanatory dictionary.

- Names connected with apparent visibility in space: промінь, освітленість, видимість.

In the Ukrainian sublanguage of astronomy according to the terminological dictionary the term промінь is polysemantic having two meanings 1) tangent which coincides with the direction of light propagation; 2) light stripe, coming from any light source or object that reflects light (Астрономічний енциклопедичний словник). The Ukrainian explanatory dictionary gives three formulas of explanation of this lexical unit: 1) acтр. fast, unexpected manifestation of something (швидкий, несподіваний прояв чого-небудь); 2) фiз. direction of propagation of energy waves (напрям поширення енергї хвиль); 3) зоол. 
bones of aquatic animals (кісточки плавиів водяних тварин) (Великий тлумачний словник сучасної української мови). It is obvious that in these interpretations of the term промінь we observe interdisciplinary polysemy- the phenomenon when terms are used in several fields of science, their terminological meanings being connected implicitly on the basis of metaphoric likeness.

Most common language meanings characterizing this group are closely connected with terminological ones being in some cases primary, but in other secondary. Ukrainian lexical units of average degree of polysemy are also characterized by the interdisciplinary polysemy of lexical units. Division of the terms into different thematic groups provided for better understanding of certain semantic features of this particular group of terms.

The investigation of the Ukrainian monosemantic terms of astronomy showed that the meanings fixed in the explanatory dictionary in most cases coincide with those suggested in terminological ones. Our research material consists of 141 monosemantic lexical units. All monosemantic terms of our Ukrainian language material are only terms of astronomy: нова зоря, відносність, анігіляція, парсек, великий вибух, електромагнітний спектр, астероїд, космічна швидкість, галактичне гало, метеор, міжзоряне середовище, метеорит, іоносфера, Кельвін, лінзоподібні галактики, світловий конус, лімб, малі планети, нововідкрита зірка еtс.

The term of astronomy парсек in the Ukraininan terminological dictionary is represented as the exogenous unit of distance in astronomy (позасистемна одиниця відстані в астрономіi) (Астрономічний енциклопедичний словник). In the explanatory dictionary it denotes: the unit of measuring the distance equal to the distance for which the annual parallax is one second (одиниця виміру відстаней, рівна відстані, для якої річний паралакс дорівнює одній секунді) (Великий тлумачний словник сучасної української мови). These two lexical meanings are rather identical being united by the semes відстань and одиниия.

The term метеop in special dictionary is explained as the phenomenon in the upper atmosphere that arise when hard particles fly 
into it (Астрономічний енциклопедичний словник). Explanatory dictionary gives the similar interpretation: a solid body of space origin, which falls with great speed in the Earth's atmosphere, a shooting star (Великий тлумачний словник сучасної української мови). The term галактика in astronomy is explained as: the giant stellar system. In the explanatory dictionary this meaning is the same: space system that consists of stars, star clusters, dust and gaseous nebulae, of diffused gas and dust. As it is obvious from the definitions, both types of dictionaries define the analyzed lexical units as the terms of astronomy. In this case we recommend marking these meanings in the explanatory dictionary by the note acmp.

Lexico-semantic analysis of the Ukrainian terms of astronomy with application of formalized approach proved that the largest group of lexical units consists of monosemantic terms. Lexical meanings provided by terminological dictionary and explanatory one are in their majority similar. Often special meaning is implicitly indicated in the explanation suggested by the explanatory dictionary. These are the cases when we recommend marking this meaning by the lexicographical note acmp.

\subsection{Seme analysis of Ukrainian astronomical terms}

Semes are the smallest elements of cognitive-semantic continuum, which are the basic building material of lexical semantics of modern language that connect not only universal cognitive-semantic scope and specific human language, but also the languages itself, regardless of their degree of kinship, descent, specificity, etc.

The study of the semantic structure of Ukrainian terms of astronomy enabled us to select 107 semes from their common language and terminological meanings. According to the amount of semantic components within the limits of lexico-semantic structure of the terms, the semes of our Ukrainian material can be described as belonging to one of the three groups: polyfunctional semes (being the elements of semantic structure of lexical units ranging from 34 to 11); semes of average degree of occurrence (selected from the words' meanings ranging from 10 to 2); 
monofunctional semes (were singled out from the meanings of only one lexical unit).

The seme composition of the Ukrainian astronomical terms is presented in the matrix and it gives a possibility to examine semes as elements of systematic - structural groups. The majority of multifunctional semes reflect common language and terminological semantics. In this group common language semantics is presented by a great number of seme realizations forming different connections. For example, the polyfunctional terminological seme тіло is represented in the special semantics of such terms as: паралакс, астероїд, фаза, афелій, метеор, метеорит, маятник, зоря, планета, затемнення, біла діра, космічна швидкість, соние еtc. In the semantics of the term соние it was singled out from the following meaning: найближча до нас зоря, центральне тіло Сонячной системи (Астрономічний енциклопедичний словник). The same seme is represented in the common language semantics of such terms: полодія, маса, протопланета, висота, опір, альбедо, акреція, супутник, суспензія. The seme елементарна частинка is the structural element of the semantics of the following terms: магнітне поле, віртуальна частинка, радіоактивність, ліброн, метеор, орбіта, квант, зодіакальне світло, мезон, атомне ядро, позитрон, спектр, кварк, протон. For example, протон - стабільна елементарна частинка, ядро протію (Астрономічний енциклопедичний словник). The seme система is a terminological seme representing special meanings of the following terms: маса, астероїд, галактика, подвійна зоря, фаза, сонще, коливання, пояс Койпера, радар, Чумаџький Шлях, Кельвін, об'єктив, рефлектор, висота. The same seme was selected from common language semantics of the terms: матерія, екліптика, радіотелескоп, ширина рівнів, акреиій ний диск, суспензія, комета, схилення, комета, Земля.

The semes of average degree of occurrence are сфера, орбіта, рух, поверхня, площина, обертання, коливання, диск, простір, речовина, середовище, температура, реакиія, одиниця, скупчення, властивість, підвищення, розмір, горизонт, траєкторія, площина, вершина, компонент, напруження, стадія, вісь, лінія еtc. For example, the 
polyfunctional terminological seme nростір is singled out in the special semantics of the terms: хвиля, сфера, магнітосфера, орбіта, космічні промені, довжина хвилі and in the common language semantics of the terms: струни, півтінь. The seme середовище is a part of semantic structure of the terms галактика, тиск, магнітосфера, локалізація, мерехтіння, суспензія, зодіакальне світло, акреція. In the semantics of the term акреція the seme середовище was selected from the meaning падіння речовини на гравітуюче космічне тіло із навколишнього середовища (Астрономічний енциклопедичний словник). The seme одиниия is a unit of the semantic structure of the terms фаза, баланс, світловий рік, маса Сония, протон, градус. The seme лінія is singled out in the lexical meanings of the terms of astronomy надгігант and нова зоря. Semantic unit блиск is a component of the semantic structure of the terms нововідкрита зірка and змінні зорі (зорі, у яких спостерігають зміни блиску хоча б в одному діапазоні) (Астрономічний енциклопедичний словник).

The monofunctional semes of the Ukrainian are: відхилення, відлік, показник, змімення, форма, координата, заряд, знак, отвір, розмивання, оболонка, тиск, смуга, заглибленняполюс, відбивати, деформація, оболонка, властивість, потік, плазма, спалах, утвори, кора, інструмент, сила, розширення, стиснення, фокусування еtс. Most monofunctional semes representing the semantics of Ukrainian terms of astronomy are of terminological character. For example, the semantic structure of the term вucoma contains the terminological seme координата in the meaning - одна з координат у горизонтальній системі небесних координат (Астрономічний енциклопедичний словник). The semantics of the term паралакс comprises the terminological seme змімення in the meaning - явище видимого змімення тіла (предмета) на тлі віддаленіших тіл у випадку змімення спостерігача. The meaning of the term сонячний вітер comprises the terminological seme потік in the meaning - безперервний потік плазми сонячної атмосфери що поширюється від Сонця у приблизно радіальних напрямках (Астрономічний енциклопедичний словник). 
The regularity of location of common language and terminological semes in the matrix represents the correlation of common language and terminological semantics of astronomy. In the semantic space of the Ukrainian language of astronomy the semes representing the semantic structure of the terms астерої (тіло, система, орбіта, відстань, розмір), фаза (тіло, система, величина, одиниця, стан, форма), Сонце (тіло, система, випромінювання), метеор (тіло, елементарна частинка, явище) display strong connections being located in the immediate vicinity in the matrix.

\section{CONCLUSIONS}

Semantic analysis of the terms of astronomy in English and Ukrainian in our research is performed with application of componential analysis and methodology of formalized analysis of lexical units' semantics, being aimed at investigation of semantic peculiarities of terms of astronomy. Matrices of semantic space of the English and Ukrainian terminological systems of astronomy were constructed. The main principle of matrix construction is rank arrangement of lexical units from the most polysemantic to monosemantic and semes from the most polyfunctional to monofunctional ones.

The analysis of the semantic space of the English and Ukrainian terms enabled us to examine such semantic phenomena as polysemy, monosemy and different connections of the investigated terms with the terminological units of other fields of study. Semantic analysis of lexical units with the highest degree of polysemy as special and common language lexemes in both languages revealed two tendencies of their semantics. In some cases, special meaning is implicitly indicated in common language explanation, thus it is recommended to mark this meaning by the lexicographical note astr. (acmp.) The opposite tendency is when the meaning in astronomy is not mentioned in the explanatory dictionary, correspondingly we suggest adding it to the rest of the meanings. In both languages in the third group of our language material common language meanings in their majority coincide with the special ones. 
Terminological monosemy in Ukrainian and English terminology of astronomy is a spread phenomenon being more characteristic of Ukrainian material than of the English one. In the semantic space, which is represented by the matrix, monosemantic lexical units occupy rather isolated place having no connections with other layers of the language system. In the Ukrainian language interdisciplinary polysemy is more spread than in English, what in the semantic space is represented by close ties between scientific meanings.

The seme composition of terms represented in the matrices allows us to examine the semes as the elements of system-structural group. A great number of multifunctional semes appeared to be the elements of terminological semantics. According to the quantitative parameter we distinguish multifunctional and monofunctional semes. The multifunctional semes occupy the first place in the matrices, uniting semantics of the majority of lexical units.

In English and Ukrainian, the parts of the matrices, reflecting the most polyfunctional semes and lexical units with wide semantics, are characterized by dense localization of semes. This testifies to their significant semantic value in the semantic space of languages. Here the astronomical semantics of English and Ukrainian terms very often coincides with that of common language vocabulary, thus the concretization is needed for their identification. In comparison with English lexical units the Ukrainian ones are not characterized by high degree of polysemy, which is reflected by smaller number of seme realizations. The number of seme realizations decreases in the direction of reduction of lexical units' polysemy and semes' frequency of occurrence. In the parts of the matrices containing monofunctional semes we can observe relatively small number of seme realizations. The semes of terminological character are arranged in isolation from each other.

Investigation of semantic basis of English and Ukrainian terms of astronomy revealed common and different features of their systemic and structural organization and identified the place and role of terms of astronomy in the language systems. 


\section{SUMMARY}

The paper deals with investigation of semantics of astronomical terminological systems in English and Ukrainian. The research is conducted with application of methodology of formalized analysis of words' semantics as terms and common language lexical units. Terminological lexis in studied on the background of semantic space of common language system with identification of its place in the lexical and semantic systems of distantly related languages, its inner structure and correlation with other terminological systems. The terms of astronomy were selected from English and Ukrainian terminological and explanatory dictionaries. The essence of methodology of the research lies in the identification of seme composition of words' lexical meanings by means of componential analysis. The synthesis of the distinguished semantic features is carried out by statistical methods, on the basis of which matrices are constructed, in the vertical order of which terms of astronomy are arranged, and in the horizontal order - the composition of semes representing meanings of the terms. The final stage of the study presupposes the comparison of the matrices' data to identify common and distinguishing features of the astronomical terminology of the two languages.

\section{REFERENCES}

1. Banczerowski J. Some contrastive considerations about semantics in the communication process // Theoretical Issues in Contrastive Linguistics. - 1980. - Vol. 12. - P. 325-345.

2. Croft W. Typology and Universals / Croft W. - Cambridge: Cambridge University Press, 1993. - 311 p.

3. Gordienko O. Some issues of English medical terminography in the context of English globalization // Сучасні дослідження з іноземної філології: Збірник наукових праць. Вип.17. - Ужгород: ДВНЗ "УжНУ", 2019. С. 25-33.

4. Jakobson Waugh L. On language. - Harvard: Harvard University Press, 1995. $-672 \mathrm{p}$. 
5. Koptjevskaja-Tam M., Vanhove M., Koch P. Typological approaches to lexical semantics. Linguistic Typology 11(1): 2007. P. 159-186.

6. Lehrer A. A theory of vocabulary structure: Retrospectives and prospectives. In Thirty years of Linguistic Evolution. Studies in honour of Rene Dirven on the occasion of his Sixtieth Birthday. - Amsterdam: John Benjamins. - 1992. - P. 243-256.

7. Talmy L. Towards a Cognitive Semantics, 2 vols. Cambridge, MA.: MIT Press. - 2000. -503 p.

8. Баранник Д.Х. Аспекти зіставного дослідження мовної семантики // Матеріали респуб. конфер. "Проблеми зіставної семантики". - Київ - Черкаси: ЧДПІ. - 1992. - С. 3-4.

9. Васильев Л.М. Достоинства и недостатки компонентного анализа в семантических исследованиях // Исследования по семантике. Межвуз. сб. - Уфа: Изд-во Башкирского университета, 1984. - C. 3-7.

10.Гумбольдт Вильгельм фон. Избранные труды по языкознанию. Пер. с нем. - М.: Прогресс, 1984. - 397 с.

11. Пещак М.М. Нариси 3 комп'ютерної лінгвістики: Монографія. - Ужгород: Закарпаття, 1999. - 200 с.

12. Потебня А.А. Психология поэтического и прозаического мышления / Потебня А.А. Слово и миф. - М., 1989. - С. 201-235.

13. Сорока Т.В. Особливості полісемантичної структури аксіономенів сучасної англійської мови // Сучасні дослідження з іноземної філології. Збірник наукових праць. - Ужгород. Вип 13. 2015. C. 197-208.

14. Фабіан М.П. Етикетна лексика в українській, англійській та угорській мовах. - Ужгород: Інформаційно-видавниче агентство "IBA", 1998. - 256 c.

\section{SOURCES}

15. Longman dictionary of contemporary English. - London: Longman group LTD, 2000. - 1966 p. 
16. Oxford dictionary of astronomy. Ridpath Ian. Oxford: Oxford University Press, 2003.-1059 p.

17. Астрономічний енциклопедичний словник / [за загальною редакцією І. А. Климишина, А. О. Корсунь]. - Львів : Видавництво ЛНУ, 2004. - 548 с.

18. Великий тлумачний словник сучасної української мови /

[уклад. і голов. ред. В. Т. Бусел]. - К. ; Ірпінь : ВТФ “Перун”, 2001. $1440 \mathrm{c.}$

Information about the author: Rohach L. V.,

Candidate of Philological Sciences, Associate Professor at the Department of English Philology Uzhhorod National University 14, Universytetska str., 88000, Uzhhorod, Zakarpattia region, Ukraine 